\title{
FOREIGN LANGUAGE BEHAVIOR OF ISLAMIC BOARDING SCHOOL STUDENTS IN WEST SULAWESI
}

\author{
Ahmad Muaffaq \\ Sekolah Tinggi Agama Islam Negeri Majene \\ Jl. BLK Kel. Totoli-Banggae, Majene, Sulawesi Barat, Indonesia \\ Email: ahmad.muaffaq@stainmajene.ac.id \\ Napis Dj \\ Universitas Islam Negeri Alauddin Makassar \\ Jl. H.M. Yasin Limpo No. 36, Romangpolong, Gowa, Sulawesi Selatan, Indonesia \\ Email: napis.djuaeni5@gmail.com
}

Article received January $28^{\text {th }}, 2021$; Article revised February $23^{\text {th }}, 2021$; Article approved May $8^{\text {th }}, 2021$

\begin{abstract}
Students of Islamic Boarding Schools in West Sulawesi come from various ethnicities. They relatively concern about their pride, loyalty, and awareness of foreign language norms as an essential part of the Islamic Boarding School curriculum. It also has an impact on the quality of its acquisition. This study aims to describe the students' behavioral patterns in using foreign languages and their factors. The data was excavated from informants on five Islamic Boarding Schools integrated with stratified random sampling models. Data collection techniques were observations, surveys, and interviews. The obtained data were carefully and critically analyzed based on data reduction, presentation, and verification methods. The results showed that the foreign languages in Islamic Boarding Schools at West Sulawesi are generally used passively because the students' activities highly focus on improving students' ability in reading. The emphasis is also on the ability to understand Arabic text. Regarding Islamic Boarding School that applies language development for reading and active communication, sociologically, students use foreign languages only in a small number of linguistic situations and in specific domains, namely education. Culturally, foreign language behavior breeds symptoms of multilingualism, bilingualism, code-switching and code-mixing, monolingualism, and interference in all linguistic situations. It is due to the responsibility, loyalty, and motivation of foreign affairs that are still lacking and the insufficient quality of teachers, environmental conditions, and curriculum content.
\end{abstract}

Keywords: foreign language behavior, language choice, language loyalty, Islamic boarding school

\section{INTRODUCTION}

$\mathrm{I}$ $\mathrm{n}$ addition to the learning process, the initial competence of prospective students greatly determines the ability of university graduates. In this context, STAIN Majene, as one of the Islamic religious universities in West Sulawesi, targets the achievement of adequate graduate competence to be absorbed well by the world of work. Language-based learning (Arabic and English) and information technology are the characteristics of this college, so prospective students with adequate linguistic competencies obtained from secondary schools are required. That is why Islamic Boarding Schools become the main target of socialization of STAIN Majene new student admissions. In fact, in Islamic Boarding Schools, Arabic and English language skills (from now on referred to as "foreign languages") are intensified and become part of the curriculum.

In contrast to the school in general, students in boarding schools have a hectic activities schedule and strict disciplines related to language disciplines. It is understandable because students are usually multilingual, coming from ethnic groups that are diverse with their own language. The diversity of the students' mother tongue allows for language contact in the Islamic Boarding School environment.

Such condition is a common phenomenon in many boarding schools in Indonesia, while boarding schools in West 
Sulawesi have their own dynamics. Based on the researchers' preliminary observations, some Islamic Boarding Schools have not implemented strict disciplines for foreign languages' use. The students' background is multilingual, coming from various tribes or ethnicities, including Mandarnese, Buginese, Makassarnese, and Javanese. Therefore, it constructs their language behavior. As a multilingual community, when interacting with teachers, administrative personnel, guards, janitors, kitchen attendants (cooks), people outside, and students' families, students have to deal with language choices (Indonesian, Arabic, English, and the local language).

Islamic Boarding Schools cannot properly control such language behavior by applying language rules and disciplines to foster awareness, responsibility, and loyalty of foreign languages, and the provision of continuous motivation. Awareness, responsibility, loyalty, and motivation are essential aspects of language behavior.

The boarding school community is famous as a devout and loyal society. The obedience and loyalty of the students create a sense of responsibility. In boarding schools, there is a social interaction between students and teachers (Kyai, Nyai, Ustadz) and administrators. Students behave respectfully and always maintain a good relationship with Kyai and Ustadz as a reflection of the students' obedience in carrying out the teachings of Islam. However, students' obedience and loyalty have not been transformed into foreign languages' responsibility as an essential part of the boarding school's coaching process in West Sulawesi.

The above circumstances encourage researchers to conduct research on foreign language behavior in boarding schools in West Sulawesi; how the patterns of students' behavior in using language are, what the language behavior situations are, and which the language choices background in daily life are. Besides, researchers found the need to conduct further research on language behaviors related to language responsibility, loyalty and adherence to language discipline choices, motivational foreign language interactions, in what context, to whom, to what, and where language behaviors carried out orally are.

Therefore, this study aims to describe foreign language students' behavior patterns at Islamic boarding schools in West Sulawesi and the factors that influence them.

\section{Literature Review}

Throughout the author's search, no one has researched the foreign language behavior of boarding school students in West Sulawesi. Meanwhile, methodologically, this research is different from the previous research since it is an interdisciplinary study that seeks to map the types of foreign languages to which speakers exhibit their behavior and interpret the mapping, both sociologically and psychologically. That was not done in previous research.

Macro linguistic studies or applied linguistics studies attract theoretical and language practitioners' interest. It is not surprising that research on language concerning various other fields is widely conducted, including research on language with society and the language user itself (sociolinguistic and psycholinguistic).

As part of the object of applied language studies, research on language behavior has actually been conducted throughout the researchers' search. For example, it is recorded that M. Ihsan has conducted a study entitled Language Behavior in Adlaniyah Islamic Boarding School in West Pasaman Regency. The study explored students' activities inside and outside the classroom. This study led to a code transfer and code-mixing in sociolinguistics that emphasized the content of the language used in communication (Ihsan, 2011).

Laode Abdul Wahab, entitled Perilaku Berbahasa Santri Pondok Modern Gontor Pudahoa, conducted another research. In the study, students' awareness, loyalty, and responsibility in maintaining Arabic, English, Indonesian, and local languages were tried to be traced. The result is that in Gontor Pudahoa Islamic Boarding Schools, the language use is adapted to the curriculum based on its level of importance (Abdul Wahab, 2014).

Rina Marnita AS and Oktaviana have also studied Perilaku Berbahasa Masyarakat Minangkabau dan Pemakaian Ungkapan 
Sebagai Madia Pendidikan Informal Keluarga. This study showed the existence and position of Minangkabau language in families and communities through common sociolinguistic symptoms called "codeswitching" and "code-mixing," in their use, both in the family and community. Besides, this study represented the attitude of young and older people relatively different from the Minangkabau language and Indonesian language, which influenced the level of knowledge and use of Minangkabau language (A.S. \& Oktavianus, 2008).

Such study results show that sociolinguistic research on language behavior is familiar but with different emphasis. The same applies to this research. This study is different from such three previous studies because it elaborates sociolinguistic analysis of intra-linguistic elements (language content) with extra-linguistic elements, which are language responsibility, loyalty, and adherence to language discipline choices, motivational foreign language interactions, with sociolinguistic and psycholinguistic approaches.

\section{Conceptual Framework}

This study used a sociolinguistic theory that examines language in the societal dimension (Nababan, 1984:2). Sociolinguistic studies discuss the characteristics and variations of language in societies (Kridalaksana, 1978:94). Similarly, the social factors play a role in language use and social associations (Kerasteh and Verkuyl in Chaer \& Leonie, 1995:5; Sumarsono, 2007:2). Thus, sociolinguistics studies the relationship between language behavior and social behavior.

Language behavior is a person's mental attitude in choosing and using language. Although everyone is free to choose and use language, many factors limit a person from choosing and using it.

Four main factors determine one's behavior: attitudes, social norms, habits, and possible consequences. This study focuses on language behavior, particularly the responsibility, loyalty, and motivation in language use (Sugar in Chaer \& Leonie, 1995:49).
Responsibility is the attitude and behavior of a person to carry out his duties and obligations, as it should be done to oneself, society, environment, country, and God (Mustari, 2011:21). It includes the responsibility of determining how to react every day in holding commitments, using resources, being tolerant and patient, being honest and fair, building courage, and showing cooperation (Aka, 2012:199).

A sense of responsibility for a task and a job is demonstrated through loyalty. Loyalty encourages a person to be serious in running his business and work selflessly. That sense of responsibility and loyalty is the motivation to do certain activities to achieve a goal (Istijanto, 2006:205).

Motivation is a desire that arises in a person consciously or unconsciously to act with a specific purpose (Salim \& Salim, 1991:997; Sardiman, 2009:73).

In addition to the sociolinguistic theory mentioned earlier, the behaviorist theory in psycholinguistics, first presented by Jhon B. Watson (1878-1958) as the development of the Stimulus-Response Bonds (SR Bonds) theory introduced by Ivan P. Pavlov, will be beneficial for the language behavior in this study.

According to SR Bonds theory, psychology's primary aims to make predictions and control behavior. If applied to language, Watson's behaviorist theory utilizes two main principles: the regency principle and frequency principle. Both psychological principles are applied to the approach of obtaining language habits that begin with impersonation.

Elaboration between sociolinguistic and psycholinguist theory will help explain foreign language behavior and control over such behavior after recognizing the patterns, as part of the acquisition and learning of foreign languages draft in the boarding school environment West Sulawesi.

\section{RESEARCH METHOD}

This study was qualitative descriptive research designed to produce descriptive data in written or spoken words (Moleong, 2000). The data was obtained from several informants who were selected by a stratified random sampling model from the students of 
four Islamic Boarding Schools spread across three districts in West Sulawesi, taking into account the type of Islamic Boarding Schools, gender, and the students' class. Data collection techniques were observation, survey, and interview techniques. Observation techniques were used to observe the Islamic Boarding Schools' conditions in West Sulawesi directly and to explore data related to foreign language behavior in general in Islamic Boarding Schools in West Sulawesi related to the selection of foreign languages in certain linguistic situations, pride in using foreign languages, and loyalty to foreign languages. Survey techniques were used to explore students' sociological behavior towards foreign languages in the educational and family domains. Interview techniques were used to explore data related to students' behavior towards foreign languages and factors that affect them. The obtained information and data were carefully and critically analyzed based on data reduction methods, data presentation, and data verification.

\section{DISCUSSION}

\section{Boarding Schools in West Sulawesi}

Boarding schools intended in this study are boarding schools as defined by Regulation of the Minister of Religious Affairs No. 13 of 2014 concerning Islamic Religious Education. According to the Minister of Religion Regulation, Islamic Boarding Schools are Islamic educational institutions held by the community that organizes Islamic Boarding School education units and/or other types of education in an integrated manner. Islamic Boarding Schools must have five elements: (1) Kyai or other similar designations, (2) students, (3) boarding schools, (4) Mosques; and (5) study of the classic book or Dirasah Islamiyah with the pattern of education Mu'allimin.

Kyai, as the first element of boarding school, is also called Annongguru in most boarding schools in West Sulawesi, especially in Polewali Mandar and Majene districts. This central figure must have a background in Islamic Boarding School education and competence in Islamic religious sciences because the main task of Kyai is to guide, nurture, and teach students. Furthermore, students as the second element are required to live in boarding schools. It is intended to further intensify the educational process, concerning worship, religious understanding, mastery of foreign languages, internalizing religious values and morals, and improving skills. Therefore, huts or dormitories become another mandatory element in addition to the Mosque (Mushalla) and recitation.

Students' obligation to live in the cottage also hints at the understanding of students in the perspective of PMA No. 13 of 2014, so that students who are outside the dormitory are not categorized as students. That became the basis for researchers to establish the study's subject, as mentioned in the title.

One of the functions of boarding schools, where the students are obliged to settle during the educational process, is the intensification of mastery of foreign languages (generally Arabic and English), in addition to the internalization of religious values and morals, and improved skills. Meanwhile, the practice of worship itself requires Mosques and religious understanding, which requires studying the classic book or Dirasah Islamiyah with the pattern of Mu'allimin education.

The five elements of boarding schools above become the basis for determining an Islamic Boarding Schools (Dhofier, 1984:44). Therefore, if the five elements are applied, some religious educational institutions that have already been called Islamic Boarding Schools from 36 boarding schools located in West Sulawesi and spread over four districts must not be included in the category of boarding schools.

Referring to Polewali Mandar Regency, there are 13 boarding schools. However, Nuhiyah Pambusuang and Al-Ikhlas do not rule Dirasah Islamiyah (Pesantrenism). Therefore, they cannot be categorized as boarding schools. Similarly, in Mamuju Regency, one of the 11 boarding schools does not organize the Islamic Boarding School education process, namely Attaufiq Pattaropura Topore, located on Poros Tarailu Topore Village Papalang Sub-district. Therefore, they are expelled from the boarding school group. 
Details of boarding schools' names in four districts in West Sulawesi can be seen in Table 1.

Table. 1: The Islamic Boarding Schools in West Sulawesi

\begin{tabular}{|c|c|c|}
\hline No. & Names of Islamic Boarding Schools & Regency \\
\hline 1 & PP. Salafiyah Pirian Tapiko & Polman \\
\hline 2 & PP. Al Ihsan Kenje & Polman \\
\hline 3 & PP. Assalafy & Polman \\
\hline 4 & PP. Modern Al Ikhlash & Polman \\
\hline 5 & PP. Syekh Hasan Yamani & Polman \\
\hline 6 & PP. Al Irsyad & Polman \\
\hline 7 & PP. Al Ihsan DDI Kanang & Polman \\
\hline 8 & PP. Salafiyah Al Wasilah Lemo & Polman \\
\hline 9 & PP. Nuhiyah & Polman \\
\hline 10 & PP. DHI Lampa & Polman \\
\hline 11 & PP. Muhdar Al Attas & Polman \\
\hline 12 & PP. GUPPI Basseang & Polman \\
\hline 13 & PP. Salafiyah Ulumul Qur'an & Polman \\
\hline 14 & PP. Al Amin DDI & Mamuju \\
\hline 15 & PP. Al Istiqamah Dolangan & Mamuju \\
\hline 16 & PP. DDI - Sumare Malauwa & Mamuju \\
\hline 17 & PP. Hidayatullah & Mamuju \\
\hline 18 & PP. Nurul Hidayah & Mamuju \\
\hline 19 & PP. Al Arif DDI Toabo & Mamuju \\
\hline 20 & PP. Attaufiq & Mamuju \\
\hline 21 & PP. Miftahul Ulum & Mamuju \\
\hline 22 & PP. Al Ikhwan & Mamuju \\
\hline 23 & PP. DDI Al- Maarif Topoyo & Mamuju \\
\hline 24 & PP. Awaluddin & Mamuju \\
\hline \multirow[t]{2}{*}{25} & PP. Assiddiq & North \\
\hline & & Mamuju \\
\hline \multirow[t]{2}{*}{26} & PP. Darul Ulum & North \\
\hline & & Mamuju \\
\hline \multirow[t]{2}{*}{27} & PP. Yadi Cab. Funju & North \\
\hline & & Mamuju \\
\hline \multirow[t]{2}{*}{28} & PP. Yayasan Nurul Jadid & North \\
\hline & & Mamuju \\
\hline \multirow[t]{2}{*}{29} & PP. Al Bana' Asing Hamzan Wadi & North \\
\hline & & Mamuju \\
\hline \multirow[t]{2}{*}{30} & PP. Al Hikmah & North \\
\hline & & Mamuju \\
\hline 31 & PP. Al Mardhiyah GUPPI Rangas & Majene \\
\hline 32 & PP. Darut Tahdzib & Majene \\
\hline 33 & PP. Ihyaul Ulum DDI & Majene \\
\hline 34 & PP. Miftahul Jihad & Majene \\
\hline 35 & PP. Jabal Rahmah Limboro & Majene \\
\hline 36 & PP. Nurul Hidayah DDI Banua & Majene \\
\hline
\end{tabular}

Apart from the restrictions given by KMA No. 13 of 2014, the education held in Islamic Boarding Schools can be grouped into four types. First, Islamic Boarding Schools that organize formal education by applying the National Curriculum, both those only have religious schools (MI, MTs, MA, and PTAI) and those that have public schools (elementary school, high school, and Islamic university). Secondly, Islamic Boarding Schools organize religious education in Madrasah and teach general sciences even though it does not apply the National Curriculum. The third is that Islamic Boarding
Schools that only teach religious sciences in the form of Madrasah Diniyah. The last is that Islamic Boarding School is just a place to study an-sich (Amin Haedari in Murtadho, 2012:16).

The varied pattern of education implementation certainly affects the intensification of language development as one of the aspects emphasized in the KMA. Therefore, the pattern of language development also can be expected to vary.

\section{Foreign Language Behavior of Students in Common}

Regarding conducting data networking, especially with observation methods, researchers involve two research assistants. Both live in boarding schools (DDI Baruga in Majene and S. Hasan Yamani Campalagian in Polewali Mandar Regency). Nevertheless, the principal researchers continued to make their observations, especially when holding specific activities related to language development. In Hasan Yamani, for example, there are Super Camp activities held annually. This year (2018) was held in Dara' Polewali. Researchers spent three days during the event observing students' behavior in various linguistic situations.

Some of the interview results indicate content related to the cottage's history, the cottage's curriculum, and teachers or caregivers who are in charge or who are responsible for the development of the students' language. That is considered necessary because foreign language behavior relies heavily on continuous coaching, the curriculum referred to, and the availability of caregivers or foreign language teachers.

To obtain complete and measurable data, in the process of data collection, researchers also disseminated written interview sheets to students who have language-coaching activities, who are spread across several Islamic Boarding Schools in three districts in West Sulawesi.

The study produced several findings that showed that foreign language behavior is more related to Arabic use in boarding schools in West Sulawesi. That is due to the development of foreign languages that emphasizes the provision of Arabic language 
skills. The widest reason is that the source of learning Dirasah Islamiyah is written in Arabic and Islamic values are instilled through that learning source. The cultivation of Islamic values is indeed the primary purpose of holding the boarding school itself.

Based on observations and interviews with informants in several boarding schools, it was found that the pattern of foreign language behavior in some boarding schools in West Sulawesi is generally passive.

Referring to Attaufiq in Mamuju, for example, students' language behavior is generally still passive. No conversations use foreign languages among students, between students and teachers, or between students and administrative employees. Nevertheless, there are indeed active actions in foreign languages through writing, even with a shallow frequency. In the field, there are writings on paper cont aining basic vocabulary and phrases in Arabic directed by students (according to the confessions of teachers and caregivers) affixed to the classroom walls.

Besides, In Miftahul Ulum, foreign language students' behavior is completely passive. As long as the researchers were at the site, foreign languages were not used among students, between students and teachers, or between students and administrative employees. Moreover, the application of two curricula, the Islamic School curriculum affiliated to the Ministry of Religious Affairs and the local curriculum (Salafiy), apparently affects students' typical foreign language behavior.

In learning Arabic and English (Islamic School curriculum), for example, occasional conversational exercises among students use Arabic or English, as is customary for these subjects to be taught. However, there is no practice of using foreign languages outside the classroom.

The classic book study (Salafiy curriculum) used three languages, namely Arabic, Javanese, and Indonesian. The teacher reads Arabic stuff, translates them into Javanese, and explains it in detail using Indonesian. Foreign language behavior only occurs passively when students listen to the classic book's contents which are read in Arabic. The QnA that occurred between the students and Kyai used Indonesian.
The students' background in Miftahul Ulum (Mandar, Bugis, and Java) is the reason for using Indonesian as the language of instruction, even though the translation uses Javanese. According to the informant, the use of Javanese as a translation language is a hereditary tradition, which no one dares to change.

In DDI Baruga, students' foreign language behavior is already active in certain activities. Every Tuesday, an extracurricular activity takes place between 18:30 and 19:30 called "Muhadharah".

The poll conducted by the editorial team of the salafiyahparappe.com website in 'Salafy Parappe', which contains the question "What motivates you to put your child into 'Salafiy Parappe'?" shows that most of the respondent's answers are to make the child independent and able to read the classic book. On the other hand, none of the respondents answered that it is to make their child able to speak Arabic.

Our interview results with Ardi, one of the students of PDF Wushtha on Thabaqah Fath Qarib II, indicate that there are language coaching activities specifically to provide active foreign language skills in Salafy Parappe. However, that only applies to the Arabic class. For instance, in Miftahul Ulum, the foreign language behavior of students is entirely passive for other classes. Foreign languages are not used among students, between students and teachers, or between students and administrative employees.

Salafy Parappe also applied two curricula, namely Wajar Dikdas Curriculum (Compulsory Learning Basic Education) and Diniyah Formal Education Curriculum. Diniyah Formal Education is an Islamic religious educational institution organized by and located in a structured and tiered Islamic Boarding School on the formal education path. The implementation of this type of education is stipulated in Regulation of the Minister of Religious Affairs No. 13 of 2014 concerning Islamic Religious Education. It is also known as informal and non-formal Diniyah education.

According to Ust. Syukur, the Head of

MTs Salafy Parappe, Wajar Dikdas Curriculum will end in 2019. Furthermore, 
only the Diniyah Formal Education Curriculum will be enforced.

In the curriculum, the structure of the Wajar Dikdas still listed English and Arabic subjects; hence, researchers estimate that foreign language activities can actively take place in the subjects' learning process. However, the observations show that teachers use Indonesian as the language of instruction.

At S. Hasan Yamani Islamic, there is language development in students since grade I. Starting from the giving of mufradat or vocabulary emphasized to be used by students even though it is still mixed with Indonesian. Entering the second year, they are required to use foreign languages (English and Arabic). Jasus (language Spiers), among the students, is disseminated to scout the behavior of the grade II students and above. Those who commit language violations will be given certain punishments.

In S. Hasan Yamani, foreign language activities are divided into Arabic Week and English Week, similar to those applied in Gontor Ponorogo. Every two weeks, there is a change of language that is required for students to be used.

The language development impacts the students' behavior, including their choice of language, loyalty, and responsibility in using Arabic and English.

1. Choice of foreign languages and language situations of students

To describe the choice of foreign languages, students are assigned 27 common linguistic situations in boarding schools in West Sulawesi experienced by students as subjects observed. These purposes will be prepared through instruments in written interviews containing 27 questions or statements about linguistic activities. Also, data is obtained from observations of the learning process inside and outside the classroom, inside and outside the Islamic Boarding School environment, and interview results recorded using a tape recorder about student language activities and conversations among students. Data is also obtained from school wall magazines, appeals, announcements, administrative documents, and notification letters.
From the research data, the linguistic situation in boarding schools in West Sulawesi can be mapped in Tabel 2 .

Table. 2: The Linguistic Situation in Islamic Boarding Schools in West Sulawesi

\begin{tabular}{|c|c|c|}
\hline \multicolumn{2}{|c|}{ No. Activities } & $\begin{array}{l}\text { Language } \\
\text { Usage }\end{array}$ \\
\hline 1 & Waking Up & $\mathrm{A} / \mathrm{E} / \mathrm{I} / \mathrm{L}$ \\
\hline 2 & Flag Ceremony & $\mathrm{A} / \mathrm{E} / \mathrm{I}$ \\
\hline 3 & Building Up Vocabulary & $\mathrm{A} / \mathrm{E} / \mathrm{I}$ \\
\hline 4 & Extracurricular & $\mathrm{A} / \mathrm{E} / \mathrm{I}$ \\
\hline 5 & Afternoon Hiking & $\mathrm{A} / \mathrm{E} / \mathrm{I} / \mathrm{L}$ \\
\hline 6 & Learning in Library & $\mathrm{A} / \mathrm{E} / \mathrm{I}$ \\
\hline 7 & Madrasah Learning & $\mathrm{A} / \mathrm{E} / \mathrm{I}$ \\
\hline 8 & PDF Learning & $\mathrm{A} / \mathrm{E} / \mathrm{I}$ \\
\hline 9 & Al-Turats Book Learning & $\mathrm{A} / \mathrm{E} / \mathrm{I}$ \\
\hline 10 & Study Together & $\mathrm{A} / \mathrm{E} / \mathrm{I} / \mathrm{L}$ \\
\hline 11 & Muhadharah & $\mathrm{A} / \mathrm{E} / \mathrm{I}$ \\
\hline 12 & Visiting Burial & $\mathrm{A} / \mathrm{E} / \mathrm{I}$ \\
\hline 13 & Cleaning Up & $\mathrm{A} / \mathrm{E} / \mathrm{I}$ \\
\hline 14 & Doing Sports & $\mathrm{A} / \mathrm{E} / \mathrm{I} / \mathrm{L}$ \\
\hline 15 & Doing the Laundry & $\mathrm{A} / \mathrm{E} / \mathrm{I} / \mathrm{L}$ \\
\hline 16 & Discussion of Al-Turats Book & $\mathrm{A} / \mathrm{E} / \mathrm{I}$ \\
\hline 17 & Wall Magazine & $\mathrm{A} / \mathrm{E} / \mathrm{I}$ \\
\hline 18 & Written Announcement & $\mathrm{A} / \mathrm{E} / \mathrm{I}$ \\
\hline 19 & Oral Announcement & $\mathrm{A} / \mathrm{E} / \mathrm{I}$ \\
\hline 20 & Correspondence & $\mathrm{A} / \mathrm{E} / \mathrm{I}$ \\
\hline 21 & Around The Mosque & $\mathrm{A} / \mathrm{E} / \mathrm{I}$ \\
\hline 22 & Around the kitchen & $\mathrm{A} / \mathrm{E} / \mathrm{I} / \mathrm{L}$ \\
\hline 23 & Around dormitory & $\mathrm{A} / \mathrm{E} / \mathrm{I} / \mathrm{L}$ \\
\hline 24 & Outside of Ponpes among Santri & $\mathrm{A} / \mathrm{E} / \mathrm{I} / \mathrm{L}$ \\
\hline 25 & Outside of Ponpes, Teachers and Santri & $\mathrm{A} / \mathrm{E} / \mathrm{I} / \mathrm{L}$ \\
\hline 26 & Outside of Ponpes, Parents and Santri & $\mathrm{A} / \mathrm{E} / \mathrm{I} / \mathrm{L}$ \\
\hline 27 & Outside of Ponpes, Societies and Santri & $\mathrm{A} / \mathrm{E} / \mathrm{I} / \mathrm{L}$ \\
\hline \multicolumn{3}{|c|}{$\mathrm{Nb}:$} \\
\hline$A=$ & \multicolumn{2}{|c|}{$=$ Arabic } \\
\hline $\mathrm{E}$ & \multicolumn{2}{|l|}{$=$ English } \\
\hline I & \multicolumn{2}{|l|}{$=$ Indonesian } \\
\hline $\mathrm{L}$ & \multicolumn{2}{|l|}{$=$ Local Language } \\
\hline
\end{tabular}

Students' choice in using a foreign language is influenced by their mental attitude: pride and loyalty in using a foreign language.

\section{Pride of using a foreign language}

Three indicators demonstrate the pride of using a foreign language: (1) attitude of upholding foreign languages, (2) awareness of the importance of foreign languages, and (3) belief in the existence of foreign languages in the era of globalization.

The attitude of upholding foreign languages is reflected in their mental attitudes during formal and informal activities. Most students, for example, recognize that foreign languages are more interesting than other languages. The use of foreign languages evidences the students' recognition as the primary language when studying. They also feel more polite when using a foreign language when discussing with classmates in learning activities related to a particular foreign language. Some feel more familiar when 
speaking foreign languages with friends in the Islamic Boarding School environment, and feel more polite and familiar when speaking foreign languages with teachers or caregivers outside the classroom in the Islamic Boarding School environment.

The students' mental attitude above indicates that they uphold a foreign language as one aspect of their pride in using a foreign language.

Students' awareness of the importance of foreign languages is demonstrated by their behavior using a foreign language when asking the teacher, answering questions asked by the teacher, and discussing with friends in the class. They also use foreign languages to communicate with friends, teachers, and caregivers outside the classroom in the boarding school environment.

The students believe Arabic/English occupies a degree equivalent to other foreign languages so that it can exist in the middle of other foreign languages in the era of globalization.

\section{Loyalty in a foreign language}

Loyalty to use a foreign language is demonstrated by two indicators: (1) the dominant attitude towards one of the foreign languages, and (2) the pleasure of using a foreign language.

The dominant attitude towards one of the foreign languages is shown by preferring to use Arabic or English in the learning process and communication events with classmates. Meanwhile, the pleasure of using a foreign language is illustrated by the recognition of those who are happy to use it in asking and answering teacher questions, in discussing, interacting, and talking with friends in the learning process, and communicating with friends, teachers, and caregivers outside the classroom in the Islamic Boarding School environment.

\section{Sociological Students' Behavior towards Foreign Languages \\ 1. Students' foreign language behavior in the educational domain}

Students' language activities in the educational domain are collected through 12 items that map language behavior in the classroom according to learning applied in
Madrasah, 17 items outside the classroom in the boarding school environment, and 4 items in communities outside the Islamic Boarding School environment.

Sociologically, in Islamic Boarding Schools that strictly absorb language development, using foreign languages is a compulsory introductory language for foreign language lessons (Arabic and English), while other subjects use Indonesian. Moreover, outside the classroom, foreign languages are required to be used as a means of communication among students, students with teachers, and the language of introduction to religious activities at a predetermined time. In this case, Arabic is spoken in two weeks Arabic Week, and English in two weeks English Week.

The answer given by the students through written interviews regarding the use of foreign languages for them is that Arabic is more widely used for Arabic lessons in the classroom. Arabic is also used in interactions outside the classroom in Islamic Boarding School environments, including religious activities. Similarly, English is more widely used for English lessons in the classroom and interactions outside the classroom. It means that the choice of Arabic and English can be interpreted as a positive attitude reflected in their pride in the language.

In addition, they are afraid or maybe ashamed if they do not use both languages in such situations. The prohibition of language causes the symptoms at certain times, in addition to Arabic and English in interactions in the Islamic Boarding School environment. That is reinforced by the sanctions given if they violate Islamic Boarding School regulations. The most widely accepted sanctions are memorizing words and terms in Arabic or English and assigning additional positive activities.

Islamic Boarding Schools that do not apply language coaching specifically, students' behavior towards foreign languages is passive and even hostile because they do not have adequate skills and are not used to using foreign languages.

\section{Foreign language behavior in the family}

Language activities in the family conducted by the students are multilingual. It is because the students also use Indonesian 
and regional languages in addition to foreign languages. Indeed, this applies to Islamic Boarding Schools that apply strict foreign language coaching, such as S. Hasan Yamani.

For analysis purposes, this multilingual language activity is excavated through four items mapping language behavior at home and in the community. Based on the researchers' findings, sociologically, students prefer not to use foreign languages for activities at home. Instead, they tend to choose Indonesian and regional languages when in the community. Furthermore, the student's behavior can be interpreted as a positive attitude reflected in their pride in the language.

For students who do not apply the language coaching strictly, the students' behavior towards foreign languages tends to be passive and even negative because it is influenced by their competence and performance that is not well built.

\section{Cultural Students' Behavior towards Foreign Languages}

The linguistic events experienced by students are determined by the culture that surrounds them. It is also determined by the language contacts with participants from diverse backgrounds, bilingual and even multilingual student backgrounds. In boarding schools in West Sulawesi, cultural language usage events can be described in Table 3 .

Students' behavior towards foreign languages is culturally demonstrated by their awareness of language norms, whose indicators focus on grammar rules and communication contexts.

Boarding school students that apply strict language coaching, such as Ponpes S. Hasan Yamani, show attention to foreign grammar rules when using them. On the other hand, standard foreign languages are more widely used in this boarding school to ask and answer teacher questions, and discuss with classmates with some grammatical interference symptoms. Meanwhile, in communicating with friends, teachers, and caregivers outside the classroom in the Islamic Boarding School environment of the students, based on the confession of a key informant, Muhammad Nur Murdan, some students often practice code-mixing and code- transfer, and interference in using foreign languages.

Table 3: The Cultural Language Usage Events in Islamic Boarding Schools in West Sulawesi Province

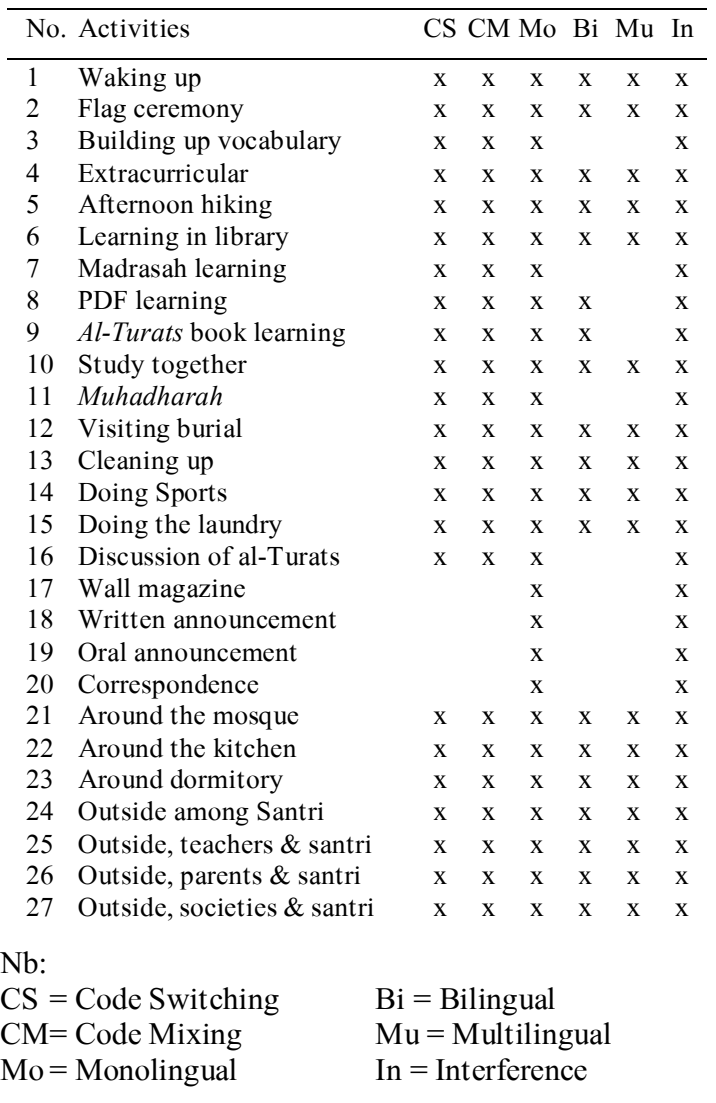

Attention to the context of the situation in the communication process is also shown by the boarding school students above. They are using a foreign language by the situation, particularly when asking and answering questions from the teacher, discussing with friends in the classroom, and communicating with friends, teachers, and caregivers outside the classroom in the Islamic Boarding Schools environment. The first context is the division of foreign language time during Arabic week and English week.

\section{Factors Influencing Foreign Language Behavior of Students}

In conducting language activities, students in West Sulawesi are influenced by several factors. From the data collected through interviews and observations, factors that affect foreign language behavior students are participants' speech, situation, the content of speech, and interaction function. Other factors are as follows. 


\section{Curriculum}

The curriculum of boarding schools in

West Sulawesi generally refers to the curriculum of Wajar Dikdas (Compulsory Learning of Basic Education) of the Ministry of Religious Affairs and the curriculum of huts affiliated to traditional Islamic Boarding Schools that prioritize the ability to understand the yellow book and several other sourcebooks. Consequently, active mastery of foreign languages (Arabic and English are not emphasized) affects the language behavior of students in this region.

Curriculum support for the language development (to obtain mastery of foreign languages both passively and actively) in boarding schools in West Sulawesi is illustrated in the curriculum, schedule of activities and books, references, or textbooks used in learning.

Salafy Parappe, for example, applies a curriculum for Diniyah Formal Education whose structure can be divided into three components: (1) Islamic religion, (2) public education, and (3) local content. The religious component of Islam consists of the subjects of the Al-Qur'an, Tafsir-Ilmu Tafsir, Hadith-Ilmu Hadith, Tawhid, Fiqh-Ushul Fiqh, AkhlakSufism, Date, Arabic, Nahwu-Sharaf, Balaghah, and Kalam Science. The general education component includes citizenship education, Bahasa Indonesia, Mathematics, and Natural Sciences.

Before being regulated by the government (KMA No. 13 of 2014), 'Salafy Parappe' also known as 'salafiyah boarding schools' still maintain a typical educational pattern of Islamic Boarding School that has long prevailed in Islamic Boarding School, either curriculum or learning methods. This institution does not use the government curriculum and only teaches religious sciences by studying classical books or commonly referred to by the Islamic Boarding School community with its classic books. The learning method also uses traditional Islamic Boarding School methods, such as sorogan, bandongan, and khalaqah (classical method) (Chirzin in Murtadho, 2012) (Chirzin in Murtadho, 2012).

After the rules are issued, Assalafy Islamic Boarding School curriculum content as an educational unit follows the curriculum set by the Ministry of Religious Affairs, which includes the Al-Qur'an, Tafsir, Tafsir, Hadith, Ulum Al-Hadith, Tawhid, Fiqh, Ushul Fiqh, Akhlak, Sufism, Date, Arabic, Nahwu-Sharf, Balaghah, Kalam Science, Arudl Science, Manthiq Science, Falaq Science, and other disciplines, as previously stated.

The learning resources used by Assalafi Parappe Islamic Boarding School in Diniyah Formal Education are 40 Arabic books, each at the Wushta and Ulya levels. Thus, it can be suspected that the curriculum structure emphasizes passive mastery of foreign languages, specifically the ability to understand the contents of classic books that use Arabic.

The activities of students in Assalafy Islamic Boarding School are arranged in such a way that the implementation of the Islamic Boarding School curriculum can run effectively. Some activities in boarding school last for an hour and a half $(06.00-07.30$ WITA), while Diniyah Formal learning lasts for 4 hours and 45 minutes $(07.45-12.30$ WITA) every day.

Compared to the learning activities in Ihyaul 'Ulum DDI Baruga-Majene, it allocates less time for the study of the classic book. It is understandable because the last Islamic boarding schools prepare more time for Islamic school learning by Islamic boarding schools' characteristics as a semi-modern Islamic boarding school. The study lasts only half to an hour. It is only on Monday (18.3019.30 WITA), Wednesday (05.30-06.00 WITA), Thursday (05.30-06.00 WITA), and Friday (18.30-19.30 WITA).

In Ihyaul 'Ulum DDI Baruga Majene, Islamic school learning takes place every day at 07.30-12.00 WITA and 13.00-15.00 WITA on Monday, 07.15-12.00 WITA and 13.0015.00 WITA on Tuesdays, Wednesdays, Thursdays, and Saturdays, and 07.15-11.30 WITA on Fridays, similar to Islamic school learning at non- Islamic Boarding School. The learning materials provided are based on the Islamic school curriculum in general.

Different things apply to Salafy Parappe. The time of Islamic school learning in Ihyaul 'Ulum DDI Baruga is used for Diniyah formal learning in Salafy Parappe presenting classic book material. 
Salafy Parappe also organizes extracurricular activities that support language skills and, of course, influence language behavior: (1) recitation of the classic book after Maghrib prayers in the cottage environment and Mosques around the village and guided directly by the caretaker of the cottage, (2) muhadharah, (3) weekly and monthly discussions of classic book among fellow students.

Curriculum support for language development that affects the students' language behavior is also reflected in the objectives of each subject formulated in the curriculum document. In Hasan Yamani, for example, Tamrīn al-Lugah al-'Arabiyyah aims to equip students with the ability to write and speak correctly by using Arabic and improve their skills in Arabic. Similarly, it is also taught Insya', which aims to equip students with the ability to select words, compose essays, and express opinions and thoughts using the correct Arabic arrangement and good language style. A complete description of the learning objectives of the subjects in the Islamic boarding schools can be seen in the appendix of this research report.

The books used by S. Hasan Yamani are generally also written in Arabic. The difference between S. Hasan Yamani and Salafy Parappe is that foreign language sourcebooks are used in S. Hasan Yamani to passively provide Arabic language skills (reading ability) (speaking and writing). The number of books used in the curriculum adopted by Gontor Ponorogo during the authors' search is 39 Books in Arabic and 5 books in Indonesian.

\section{Motivation and habit}

Motivation to use a foreign language orally in the boarding school of West Sulawesi is very lacking, so most foreign language interactions are implemented in writing, such as wall magazines, even tending to be one-way or only in the form of expression. Thus, the desire to benefit from the selection of foreign languages in communication is not well embedded. That has an impact on their habits that are not built early on. In fact, habit is the most powerful factor influencing language behavior.
3. Age

In Islamic Boarding Schools with a language development program, students' age affects their proficiency in using foreign languages. In addition, the choice of language, responsibility, and loyalty of foreign languages, especially Arabic, is influenced by how long they stay in the cottage.

\section{Teachers}

In general, teachers in the students' environment have a good mastery of the Indonesian language but lack their mastery of foreign languages. However, exceptions are given to teachers of Arabic and English.

\section{Environment}

The language environment is not well-formed, so it is rather difficult for students to choose a foreign language to communicate. There is no policy requiring foreign languages, such as Arabic Week and English Week.

\section{CLOSING}

Generally, students' foreign language behavior in Islamic Boarding Schools in West Sulawesi is passive, except in some boarding schools that hold language coaching, including S. Hasan Yamani and Salafy Parappe in Polewali Mandar and Al-Ihsan Baruga in Majene.

After being mapped into 27 linguistic situations, it was found that most of the situations became the background of the use of Indonesian and, a small part became the background of the use of foreign languages. Meanwhile, in 11 linguistic situations, students are more likely to use the local language.

In boarding schools that apply strict language coaching toward the family, students are more likely to choose not to use a foreign language for activities at home. Instead, they generally tend to choose Indonesian and regional languages when in the community. The student's behavior can be interpreted as a positive attitude reflected in their pride in the language. Meanwhile, in the domain of education, foreign languages are compulsory introductory languages for foreign language lessons. While for other subjects, they use Indonesian. Outside the classroom, foreign languages are required to 
be used as a means of communication among students, students with teachers, and the language of introduction to religious activities at a predetermined time.

Culturally, foreign language behaviors create linguistic events or symptoms in the form of multilingualism in 17 linguistic situations, bilingualism in 19 linguistic situations, code transfer and mix in 23 linguistic situations, and monolinguals and interference in all linguistic situations.

The foreign language behavior of students who tend to be passive is more influenced by the function of interaction, especially motivation and habits, teachers, curriculum, and environment. The condition is certainly not favorable for the State Islamic College (STAIN) Majene and the boarding school. Therefore, researchers recommend intensive language development even though it is in boarding schools of Assalafy, regular alumni recruitment to overcome the limited human resources of foreign language teachers/trainers, curriculum revisions in favor of language development, and the creation of a good language environment for students.

\section{ACKNOWLEDGEMENT}

This article has undoubtedly involved many parties, directly or indirectly; hence, it could be accomplished properly. Thus, the author should express his gratitude to Muhammad Nur Murdan, S.Th.I, M.Th.I., Muh. Arham, S.Pd., M.Pd., and students of DDI Baruga In Kab. Majene, Ponpes S. Hasan Yamani and Ponpes Salafiyah Parappe in Polewali Mandar, Ponpes Al-Taufik and Ponpes Miftahul Ulum in Mamujuyang District, who assisted in data collection. Similar remarks from the author conveyed to Nur Fadillah Nurchalis, M.Pd., for her willingness to provide language assistance. The author also gave his highest appreciation to STAIN Majene, which has funded this research, and the editorial team of Al Qalam Journal, who has edited this article so that it is considered worthy of publication.

\section{REFERENCES}

A.S., R. M., \& Oktavianus. (2008). Perilaku Berbahasa Masyarakat Minagkabau dan Pengaruhnya terhadap Pemakaian
Ungkapan Sebagai Media Pendidikan Informal Keluarga. Linguistik Indonesia, 26(2).

Abdul Wahab, L. (2014). Perilaku Berbahasa Santri Pondok Modern Gontor Pudahoa. Al-Izzah: Jurnal Hasil-Hasil Penelitian, 9(1).

Aka, H. (2012). Guru yang Berkarakter Kuat. Jakarta: Laksana.

Chaer, A., \& Leonie, A. (1995). Sosiolinguistik Perkenalan Awal. Jakarta: PT. Rineka Cipta.

Dhofier, Z. (1984). Tradisi Pesantren: Studi tentang Pandangan Hidup Kyai (Cet. Ke-3). Jakarta: Lembaga Penelitian, Pendidikan, dan Penerangan Ekonomi dan Sosial.

Ihsan, M. (2011). Perilaku Berbahasa Di Pondok Pesantren Adlaniyah Kabupaten Pasaman Barat. Jurnal Elektronik WACANA ETNIK, 2(1), 2538. Retrieved from http://wacanaetnik.fib.unand.ac.id/inde x.php/wacanaetnik/article/view/17/19

Istijanto. (2006). Riset Sumber Daya Manusia Cara Praktis Mendeteksi DimensiDimensi Kerja Karyawan. Jakarta: PT Gramedia Pustaka Utama.

Kridalaksana, H. (1978). Beberapa Masalah Linguistik Indonesia. Jakarta: Universitas Indonesia, Fakultas Sastra.

Moleong, L. J. (2000). Metodologi Penelitian Kualitatif. Bandung: Rosdakarya.

Murtadho, A. (2012). Kebijakan Wajar Dikdas 9 Tahun Pola Pondok Pesantren Salafiyah. Jurnal Forum Tarbiyah, 10(Nomor 2 Desember).

Mustari, M. (2011). Nilai Karakter Refleksi untuk Pendidikan Karakter. Yogyakarta: LaksBang PRESSindo.

Nababan, P. W. . (1984). Sosiolinguistik: Suatu Pengantar (Cet. I). Jakarta: PT. Gramedia.

Salim, P., \& Salim, Y. (1991). Kamus bahasa Indonesia kontemporer. Jakarta: Modern English Press.

Sardiman. (2009). Interaksi dan Motivasi Belajar Mengajar. Jakarta: Rajawali Pres.

Sumarsono. (2007). Soiolinguistik. Yogyakarta: Lembaga Studi Agama, Budaya, dan Perdamaian. 